\title{
"A model for analyzing the financial stability of banks in the VUCA-world conditions"
}

\begin{tabular}{|c|c|}
\hline \multirow{7}{*}{ AUTHORS } & Svitlana Khalatur (D) https://orcid.org/0000-0001-8331-3341 \\
\hline & R https://publons.com/researcher/T-7645-2019 \\
\hline & Liudmyla Velychko (D https://orcid.org/0000-0002-8255-8774 \\
\hline & R https://publons.com/researcher/2015009/velichko-lyudmila/ \\
\hline & Olena Pavlenko (D https://orcid.org/0000-0003-3557-3338 \\
\hline & Oleksandr Karamushka (D https://orcid.org/0000-0002-9369-7972 \\
\hline & Mariia Huba \\
\hline ARTICLE INFO & $\begin{array}{l}\text { Svitlana Khalatur, Liudmyla Velychko, Olena Pavlenko, Oleksandr Karamushka } \\
\text { and Mariia Huba (2021). A model for analyzing the financial stability of banks in } \\
\text { the VUCA-world conditions. Banks and Bank Systems, 16(1), 182-194. } \\
\text { doi:10.21511/bbs.16(1).2021.16 }\end{array}$ \\
\hline DOI & http://dx.doi.org/10.21511/bbs.16(1).2021.16 \\
\hline RELEASED ON & Tuesday, 30 March 2021 \\
\hline RECEIVED ON & Thursday, 10 September 2020 \\
\hline \multirow[t]{2}{*}{ ACCEPTED ON } & Thursday, 18 March 2021 \\
\hline & $(\mathrm{ccc}) \mathrm{EY}$ \\
\hline LICENSE & $\begin{array}{l}\text { This work is licensed under a Creative Commons Attribution } 4.0 \text { International } \\
\text { License }\end{array}$ \\
\hline JOURNAL & "Banks and Bank Systems" \\
\hline ISSN PRINT & $1816-7403$ \\
\hline ISSN ONLINE & $1991-7074$ \\
\hline PUBLISHER & LLC “Consulting Publishing Company "Business Perspectives" \\
\hline FOUNDER & LLC "Consulting Publishing Company "Business Perspectives" \\
\hline
\end{tabular}

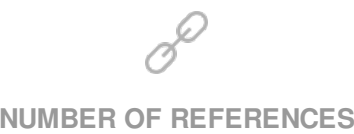

29

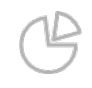

NUMBER OF FIGURES

2

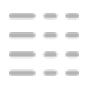

NUMBER OF TABLES

5

(C) The author(s) 2021. This publication is an open access article. 


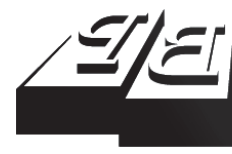

\section{BUSINESS PERSPECTIVES}

()

LLC "CPC "Business Perspectives"

Hryhorii Skovoroda lane, 10, Sumy, 40022, Ukraine www.businessperspectives.org
Received on: $10^{\text {th }}$ of September, 2020 Accepted on: $18^{\text {th }}$ of March, 2021 Published on: $30^{\text {th }}$ of March, 2021

(c) Svitlana Khalatur, Liudmyla Velychko, Olena Pavlenko, Oleksandr Karamushka, Mariia Huba, 2021

Svitlana Khalatur, Doctor of Economics, Professor of the Finance, Banking and Insurance Department, Dnipro State Agrarian and Economic University, Dnipro, Ukraine. (Corresponding author)

Liudmyla Velychko, Ph.D. in Public Administration, Senior Lecturer, Department of Economics, Entrepreneurship and Management of Enterprises, Oles Honchar Dnipro National University, Dnipro, Ukraine.

Olena Pavlenko, Ph.D. in Economics, Associate Professor, Department of Economics, Dnipro State Agrarian and Economic University, Dnipro, Ukraine.

Oleksandr Karamushka, Ph.D. in Economics, Associate Professor, Department of Information Systems and Technologies, Dnipro State Agrarian and Economic University, Dnipro, Ukraine.

Mariia Huba, Ph.D. in Economics, Associate Professor, Department of Banking and Financial Services, University of Customs and Finance, Dnipro, Ukraine.
Svitlana Khalatur (Ukraine), Liudmyla Velychko (Ukraine), Olena Pavlenko (Ukraine), Oleksandr Karamushka (Ukraine), Mariia Huba (Ukraine)

\section{A MODEL FOR ANALYZING THE FINANCIAL STABILITY OF BANKS IN THE VUCA-WORLD CONDITIONS}

\begin{abstract}
VUCA is a chaotic and rapidly changing business environment that, based on the variability, uncertainty, complexity and ambiguity of the modern world, transforms the approach of banks to the analysis of financial stability. The aim of the paper is to improve tools for monitoring the impact of VUCA-world conditions on the financial stability of banks, namely a model for studying and analyzing the impact of the modern business space "VUCA" on the financial stability of the country's banks. To test the model, the method of constructing regression equations in multifactor regression analysis is used. For this study, data from some Eastern European countries (Ukraine, Belarus, Latvia, Lithuania, Moldova) were used, and time series data were used for 10 years from 2010 to 2019 .

Having considered the definition of "VUCA-world conditions", the model of modern business space "VUCA" was developed when analyzing the activity of banks in the studied countries. Drivers, consequences, requirements and macroeconomic indicators of the countries' activities in the VUCA-world conditions are determined. The VUCA-world conditions also consider the study of key macroeconomic indicators that allow building long-term relationships throughout the value chain. The analysis of the studied Eastern European countries showed that with the increase of factors of GDP growth, GNI per capita growth, research and development costs, foreign direct investment, and net inflow of $1 \%$, the effective ratio of bank capital and assets also increases. The assessment, in contrast to the existing ones, makes it possible to consider the impact of the macroeconomic environment of banks on their financial stability.
\end{abstract}

\section{Keywords}

bank activity, macroeconomic indicators, efficiency, VUCA-response, volatility, uncertainty, complexity, ambiguity

JEL Classification C51, G21, F36

\section{INTRODUCTION}

The difficult financial situation in the banking sector of Ukraine is evidenced by the importance of the International Global Competitiveness Index (WEF) for the Financial Sector, according to which in 2019 Ukraine, with an index of 42.3, ranks 136 among 141 countries participating in the ranking. The situation is not better with regard to the stability of the financial sector of Ukraine. According to the overall rating on the stability of the financial sector, Ukraine ranks last among all countries - 141 with an index of 57.6, in terms of bank reliability - 131 (index - 37.4).

The challenges of the accelerated process of globalization and transnationalization, the unpredictable course of events in the world economy, burdened by the prolonged global crisis and political hybrid catagenesis, require significant efforts from the business environment to make significant changes in economic, organizational, technological, innovative and vector directions of develop- 
ment. Therefore, the scientific and applied problem of analyzing the financial stability of banks in the VUCA-world is relevant.

Particular attention should be paid to the development of a model for studying the impact of the modern business space "VUCA" on the analysis of the financial stability of banks in the country, based on modern intelligent information systems with continuous monitoring of external and internal conditions of rapid transformation processes in the global economic and national systems, which requires timely changes in strategy development of banks to coordinate efforts for leadership in the economic environment. VUCA-world requires the creation of new patterns of perception and information collection, as well as the development of numerous strategies and plans for the future.

Thus, today the banking system of Ukraine operates in a complex socio-economic and legal environment, most factors of which - macroeconomic instability, irrational structure of the industrial complex, the crisis of science and technology, imperfect fiscal and monetary policy, low effective demand - complicate stable development of the banking sector and increase competitiveness. In the context of instability and intensified turbulent processes, the development of banks requires new approaches to defining and analyzing financial stability based on the VUCA-world.

\section{THEORETICAL BASIS}

When analyzing theoretical bases of the research, the work of scientists in the following areas was studied: activity of banks in volatility, uncertainty, complexity and ambiguity conditions of business-environment.

Regarding the study of banks in the changing business environment, Nidar et al. (2020) note that one of the evaluated indicators of banks is their efficiency. Highly efficient banks are considered competitive and productive. The efficiency of a bank is important for estimating its performance. The efficiency of bank performance is becoming increasingly used by banks and banking regulators in the world, whereas the competition between banks is more widespread not only in certain regions and certain countries, but also in banks operating in different countries.

Donatosi and Giokasii (2008) studied new mathematical programming models related to the degree at which each bank branch makes use of its resources and applied to deal with the weaknesses of efficiency ratios. Dardac and Boitan (2009) confirm that moving from conformity with the prudential banking regulation approach to a risk-based approach requires updating traditional surveillance methods by adding up new techniques in order to assess, in real time, the adverse changes occurred in bank activity, which can increase the bank risk exposure.
The activity of banks in the uncertain business environment is studied by Rakhmetova et al. (2020) who note that in most European countries, venture capital has developed significantly with the support of the financial sector and the state, which have begun to play the role of a co-financier, organizer, source of information and customer. Despite the complexity of implementing this form of interaction (venture business is very risky, and financial institutions cannot risk borrowed funds), the prospects for the development of this form of interaction between the financial and innovation sectors of the economy are associated with the transition to innovation. Cenkhan et al. (2020) study the systemic risks of banks. In stress tests, the implications for individual banks' financial positions under several macroeconomic scenarios are examined.

Some aspects of banks in the complexity of the business environment are analyzed by Shuyan and Fabuš (2019), who write that unilateralism and counter-globalization have increased in recent years, which has had a greater impact on global economic growth, trade and investment. Bortnyk et al. (2018) studied financial investigation in the countries with legal systems close to the Ukrainian one, which is formulated as criminal proceedings in cases of crimes committed in the field of economics and finance. Batischeva et al. (2018) investigate the effect of the interaction of a region and its banking system, the approaches 
to analyzing bank activities on the region and its socio-economic indicators. Cont et al. (2020) applied liquidity stress tests, in parallel to and independently from solvency stress tests, based on scenarios that may not be consistent with those used in solvency stress tests in banks.

The peculiarities of banks' activity in the ambiguity of the business environment are analyzed by Halunko et al. (2018), who argue that small and medium enterprises should develop and receive financial support from the state and credit institutions along with big enterprises. Scientists also study foreign experience, which allows them to identify common features of financial and credit support mechanisms that should be taken into account in native practice. Banae Costa and Chagas (2004) describe various measures taken to build the model that addresses the scoring of medium and longterm loans to firms in the context of the banking sector, using the Macbeth interactive approach.

Codreanu (2016) argues that today the acronym VUCA accurately reflects the effects of high mobility of people, goods and services caused by the opening of state borders or reconfiguration at the mental, technological and physical levels, as well as the evolution of technical interconnections.

Singhwal (2018) writes that at VUCA world, experts and managers note that the main activities needed to stimulate the effectiveness of an organization, such as strategic planning, are only exercises for futility. VUCA's terms make any effort to understand future developments futile. Sinha (2020) notes that the level of uncertainty is rising sharply and prevails in the modern world. There are no simple solutions to the world's problems, they have become so complex. There is a complete lack of clarity in almost everything that concerns the global economy. Nangia and Mohsin (2020) write that the VUCA model has been adopted by business leaders around the world to optimally approach various types of difficult situations caused by various external factors. Given the rapid changes on the social, economic, political and technological fronts, the COVID-19 pandemic has become an excellent example of VUCA.

Having analyzed previous research, the need for a more detailed study of banking activities and estimation of financial stability of banks in the VUCA-world environment was identified, which confirms the relevance of the study.

\section{AIMS}

The paper aims to improve tools for monitoring the impact of VUCA-world conditions on the financial stability of banks, namely a model for studying and analyzing the influence of modern business space "VUCA" on the financial stability of banks.

\section{RESULTS}

The concept of the VUCA world, which is actively used in the business environment, in particular during analyzing financial stability of banks, becomes an integral phenomenon and extends to other areas of society. The theoretical achievements of foreign and Ukrainian scientists about the requirements of the VUCA environment should be widely used in the analysis of financial stability of banks. VUCA is an acronym formed by the initial letters of four words: Volatility, Uncertainty, Complexity and Ambiguity. Volatility provides that the situation is changing so quickly and unpredictably that it is impossible to plan further actions and try to predict the future situation based on data about these changes. Uncertainty makes it difficult to determine future changes. Complexity means that the problem is formed with a complex of complicate facts, causes and factors. Ambiguity implies ambivalence, uncertainty in the answers to the questions "Who?", "What?", "When?", and "Why?". It is believed that the VUCA world has replaced the SPOD-world, which was a Steady (hard), Predictable (anticipated), Ordinary (simple), Definite (fixed) environment. In such environment SPOD-strategies have been developed and demonstrated their effectiveness, they have been used for a long time by various management entities, mainly in the economic field. With their use, it became possible to achieve desired goal. The key task was to choose the SPOD-strategy that would be most effective in a particular case. The right choice was the key to a successful solution. In the new VUCA environment these strategies are ineffective; and new ones must provide adapt- 
ability, ability to respond quickly to changes in the external environment. Therefore, specialists of the "new formation" and heads of banking institutions should take into account, in the course of their, activity that previous experience is not always useful in solving forthcoming problems, and continuity and dependence of previous development stages are not guaranteed.

Due to the variability and rapidity of the environment, the theoretical and practical developments in responding to the challenges of the VUCA world should be reflected in the bank activity, first of all, when developing a model for analyzing the financial stability of banks.

In this regard, the application of the theory "VUCA-response to VUCA-challenges" is important for developing a theory and practice of financial stability of banks in Ukraine. Its groundwork is associated with the name of the British economist K. Roberts. "VUCA-response to VUCAchallenges" is also an acronym formed by the initial letters of four words: Vision, Understanding, Creativity/Clarity, and Agility. Vision, in terms of bank financial stability, provides a clear goal, consistency and focus on the key tasks of all parties involved. Understanding means constant monitoring of expectations of service recipients, ability to cooperate and response to constructive criticism. Clarity is simplification (rejection of the unnecessary things, leaving the essence of the problem), the use of intuition and experience, systematic thinking. Agility involves determination, adaptability, innovations and continuous improvement; in the bank activity it implies the greater value of horizontal links than a clear hierarchy, establishing cooperation instead of control; and the importance of empowerment to achieve the desired results. It is necessary to study the regulations of this concept in terms of their application in theory and practice of ensuring the financial stability of Ukrainian banks.

To achieve the objectives of this paper, the financial stability of a bank is defined as a qualitative dynamic characteristic reflecting its ability to perform its functions when adapting to the external environment with positive changes in financial indicators or maintaining them within certain limits, regardless of internal factors. Thus, the stabil- ity of banks is determined by the conditions and factors that are formed at the level of a particular institution (micro level) and at the environmental level (macro level). Ensuring financial stability involves regular monitoring and analysis of various vulnerabilities and risks to the financial system based on macroeconomic indicators and the appropriate response to them. Also, for the purposes of this study, the model is understood as the reproduction of the idea and calculations, imitating the characteristics of the banks functioning in the VUCA world.

For further analysis of the financial stability of banks in the VUCA world, the main indicators of the bank activity of Eastern European countries (namely, Ukraine, Belarus, Latvia, Lithuania, Moldova), which are available for analysis, were studied.

The average value of the banks in the Eastern European countries is analyzed in Table 1.

Table 1 shows that the deposit interest rate (\%) is the highest in Belarus, with a relatively low number of commercial bank branches (per 100,000 adults), compared to other countries under study. In Ukraine, among the studied countries, the following indicators are the highest: bank nonperforming loans to total gross loans (28.84\%), commercial banks and other lending (PPG + PNG) (NFL, 2,430,796,764 current USD), commitments, private creditors (COM, 2,882,796,133 current USD), depositors with commercial banks $(2,601.97$ per 1,000 adults), domestic credit provided by financial sector $(68.15 \%$ of GDP), undisbursed external debt, private creditors (UND, 182,547,099 current USD).

To substantiate the components of model for analyzing banks' financial stability in the VUCAworld conditions, Table 2 analyzes the general indicators of the economic development of the studied countries on average during 2010-2019 in the VUCA-world conditions.

Table 2 shows that Latvia is the most economically stable and developed among the studied countries of Eastern Europe.

The Gini index measures the extent to which the distribution of income among individuals or 
Table 1. Average value of bank performance in some Eastern European countries on average for the period 2010-2019

Source: Authors' calculations according to the data from the World Bank.

\begin{tabular}{|c|c|c|c|c|c|}
\hline \multirow{2}{*}{ Indicator } & \multicolumn{5}{|c|}{ Country name } \\
\hline & Ukraine & Belarus & Latvia & Lithuania & Moldova \\
\hline Bank capital to assets ratio (\%) & 12.49 & 13.76 & 9.78 & 10.17 & 15.96 \\
\hline Bank liquid reserves to bank assets ratio (\%) & 8.80 & 14.73 & - & - & 24.62 \\
\hline Bank nonperforming loans to total gross loans (\%) & 28.84 & 6.81 & 8.25 & 11.86 & 14.12 \\
\hline Commercial bank branches (per 100,000 adults) & 2.18 & 3.05 & 27.96 & 22.12 & 36.07 \\
\hline $\begin{array}{l}\text { Commercial banks and other lending (PPG + PNG) (NFL, } \\
\text { current USD) }\end{array}$ & $2,430,796,764$ & $19,600,647$ & - & - & $72,177,941$ \\
\hline Commitments, official creditors (COM, current USD) & $1,492,768,784$ & $2,156,719,151$ & - & - & $183,975,107$ \\
\hline Commitments, private creditors (COM, current USD) & $2,882,796,133$ & $585,680,296$ & - & - & $5,460,837$ \\
\hline Deposit interest rate (\%) & 9.97 & 15.34 & - & - & 11.77 \\
\hline Depositors with commercial banks (per 1,000 adults) & $2,601.97$ & - & $1,242.44$ & - & $1,029.72$ \\
\hline Depth of the credit information index $(0=$ low to $8=$ high $)$ & 7.00 & 6.50 & 7.00 & 8.00 & 5.00 \\
\hline Domestic credit provided by financial sector (\% of GDP) & 68.15 & 31.93 & 64.61 & 51.74 & 35.59 \\
\hline Domestic credit to private sector (\% of GDP) & 53.22 & 23.32 & 60.75 & 45.50 & 30.41 \\
\hline Domestic credit to private sector by banks ( $\%$ of GDP) & 45.34 & 21.90 & - & 45.49 & 29.12 \\
\hline Firms using banks to finance investment (\% of firms) & 23.95 & 23.25 & 25.75 & 27.28 & 27.72 \\
\hline Firms using banks to finance working capital (\% of firms) & 19.00 & 21.23 & 27.47 & 27.88 & 30.58 \\
\hline GINI index (World Bank estimate) & 26.50 & 27.62 & 36.03 & 35.50 & 31.99 \\
\hline IBRD loans and IDA credits (DOD, current USD) & $3,319,869,529$ & $303,171,176$ & - & - & $472,848,705$ \\
\hline Interest arrears, private creditors (current USD) & $1,171,982,423$ & $2,883,623$ & - & - & $39,955,087$ \\
\hline Net domestic credit (thou. current LCU) & $779,238,281$ & $13,655,976$ & $14,464,625$ & $18,074,750$ & $25,286,033$ \\
\hline $\begin{array}{l}\text { PNG, commercial banks and other creditors (AMT, } \\
\text { current USD) }\end{array}$ & $9,093,841,000$ & $745,762,960$ & - & - & $226,794,176$ \\
\hline Principal arrears, official creditors (current USD) & $64,429,749$ & $1,542,931$ & - & - & $5,470,503$ \\
\hline Principal arrears, private creditors (current USD) & $4,204,200,530$ & $9,719,399$ & - & - & $158,220,764$ \\
\hline $\begin{array}{l}\text { Undisbursed external debt, official creditors (UND, } \\
\text { current USD) }\end{array}$ & $2,091,660,348$ & $5,498,642,022$ & - & - & $562,179,020$ \\
\hline $\begin{array}{l}\text { Undisbursed external debt, private creditors (UND, } \\
\text { current USD) }\end{array}$ & $182,547,099$ & $63,786,960$ & - & - & $3,783,104$ \\
\hline Capital profitability of banks, $\%$ & 21.1 & 9.6 & - & - & 7.8 \\
\hline
\end{tabular}

Table 2. General indicators of development of the studied countries' economies on average for 20102019 in the VUCA world conditions

Source: Authors' calculations according to the data from the World Bank.

\begin{tabular}{|c|c|c|c|c|c|}
\hline \multirow{2}{*}{ Indicator } & \multicolumn{5}{|c|}{ Country } \\
\hline & Ukraine & Belarus & Latvia & Lithuania & Moldova \\
\hline $\begin{array}{l}\text { Adjusted net national income per capita (annual \% } \\
\text { growth) }\end{array}$ & 5.33 & 6.93 & 6.00 & 6.98 & 6.29 \\
\hline Adjusted net national income per capita (current USD) & $2,064.91$ & $4,305.69$ & $8,653.89$ & $7,207.84$ & $1,453.55$ \\
\hline Broad money (\% of GDP) & 47.09 & 26.09 & - & - & 46.93 \\
\hline Central government debt, total (\% of GDP) & 41.41 & 20.24 & - & - & 33.86 \\
\hline Current account balance (\% of GDP) & -0.84 & -5.50 & -5.75 & -4.45 & -7.72 \\
\hline $\begin{array}{l}\text { Current education expenditure, total (\% of total } \\
\text { expenditure in public institutions) }\end{array}$ & 96.05 & 93.13 & 87.31 & 90.92 & 91.54 \\
\hline Current health expenditure (\% of GDP) & 6.37 & 5.73 & 5.77 & 6.24 & 9.95 \\
\hline Expense (\% of GDP) & 36.12 & 29.25 & 43.22 & 33.79 & 31.33 \\
\hline Exports of goods and services (\% of GDP) & 48.78 & 62.48 & 48.76 & 63.04 & 45.35 \\
\hline External balance on goods and services (\% of GDP) & -3.22 & -3.49 & -7.79 & -3.79 & -37.17 \\
\hline Final consumption expenditure (\% of GDP) & 81.04 & 70.56 & 79.83 & 82.56 & 110.56 \\
\hline Foreign direct investment, net inflows ( $\%$ of GDP) & 3.95 & 2.45 & 3.59 & 2.92 & 5.40 \\
\hline Foreign direct investment, net outflows (\% of GDP) & 0.22 & 0.03 & 0.86 & 0.89 & 0.19 \\
\hline GDP growth (annual \%) & 2.34 & 4.72 & 3.85 & 4.20 & 4.76 \\
\hline
\end{tabular}


Table 2 (cont.). General indicators of development of the studied countries' economies on average for 2010-2019 in the VUCA world conditions

\begin{tabular}{|c|c|c|c|c|c|}
\hline \multirow{2}{*}{ Indicator } & \multicolumn{5}{|c|}{ Country } \\
\hline & Ukraine & Belarus & Latvia & Lithuania & Moldova \\
\hline GINI index (World Bank estimate) & 26.50 & 27.62 & 36.03 & 35.50 & 31.99 \\
\hline GNI growth (annual \%) & 2.71 & 4.54 & 3.76 & 3.40 & 5.20 \\
\hline GNI per capita growth (annual \%) & 3.59 & 4.85 & 4.96 & 4.77 & 5.36 \\
\hline Government expenditure on education, total (\% of GDP) & 5.97 & 5.12 & 5.40 & 5.01 & 7.34 \\
\hline Gross capital formation (\% of GDP) & 23.22 & 32.66 & 27.96 & 21.24 & 26.61 \\
\hline Gross national expenditure (\% of GDP) & 104.26 & 103.22 & 107.79 & 103.79 & 137.17 \\
\hline Imports of goods and services (\% of GDP) & 52.00 & 65.97 & 56.55 & 66.84 & 82.52 \\
\hline Inflation, GDP deflator (annual \%) & 16.23 & 28.17 & 4.79 & 2.89 & 9.02 \\
\hline Lending interest rate (\%) & 18.74 & 17.41 & - & - & 17.45 \\
\hline $\begin{array}{l}\text { Market capitalization of listed domestic companies (\% of } \\
\text { GDP) }\end{array}$ & 16.32 & - & - & - & - \\
\hline Military expenditure (\% of GDP) & 2.85 & 1.39 & 1.35 & 1.12 & 0.41 \\
\hline Present value of external debt (\% of GNI) & 20.89 & 18.18 & - & - & 7.00 \\
\hline Profit tax (\% of commercial profits) & 11.24 & 18.18 & 6.16 & 6.51 & 7.14 \\
\hline Research and development expenditure (\% of GDP) & 0.83 & 0.65 & 0.54 & 0.82 & 0.40 \\
\hline Researchers in R\&D (per million people) & 1240.15 & - & 1705.54 & 2539.05 & 752.29 \\
\hline Tax revenue ( $\%$ of GDP) & 16.78 & 16.96 & 21.24 & 17.87 & 17.98 \\
\hline Trade (\% of GDP) & 100.79 & 128.45 & 105.31 & 129.88 & 127.87 \\
\hline
\end{tabular}

households in the economy deviates from an ab- For the purposes of this paper, the model means the solutely uniform distribution. Thus, the Gini in- reproduction of the description and calculations that dex of 0 represents perfect equality, while the in- reflect the principles of operation, certain properties, dex of 100 indicates perfect inequality. According to the GINI index (Figure 1), Ukraine ranks fifth in 2001-2019 on average, compared to the Eastern European countries. According to the UN, more than $60 \%$ of the population lives below the poverty line in Ukraine, but according to the World Bank, this value is $25 \%$. features and characteristics of banks in terms of the VUCA world. Table 3 offers a model for studying the impact of modern business space "VUCA" on the analysis of financial stability of the country's banks.

Table 3 shows the system of modern business space "VUCA" in the analysis of the bank activity of the

Source: Compiled by the authors based on data from the World Bank.

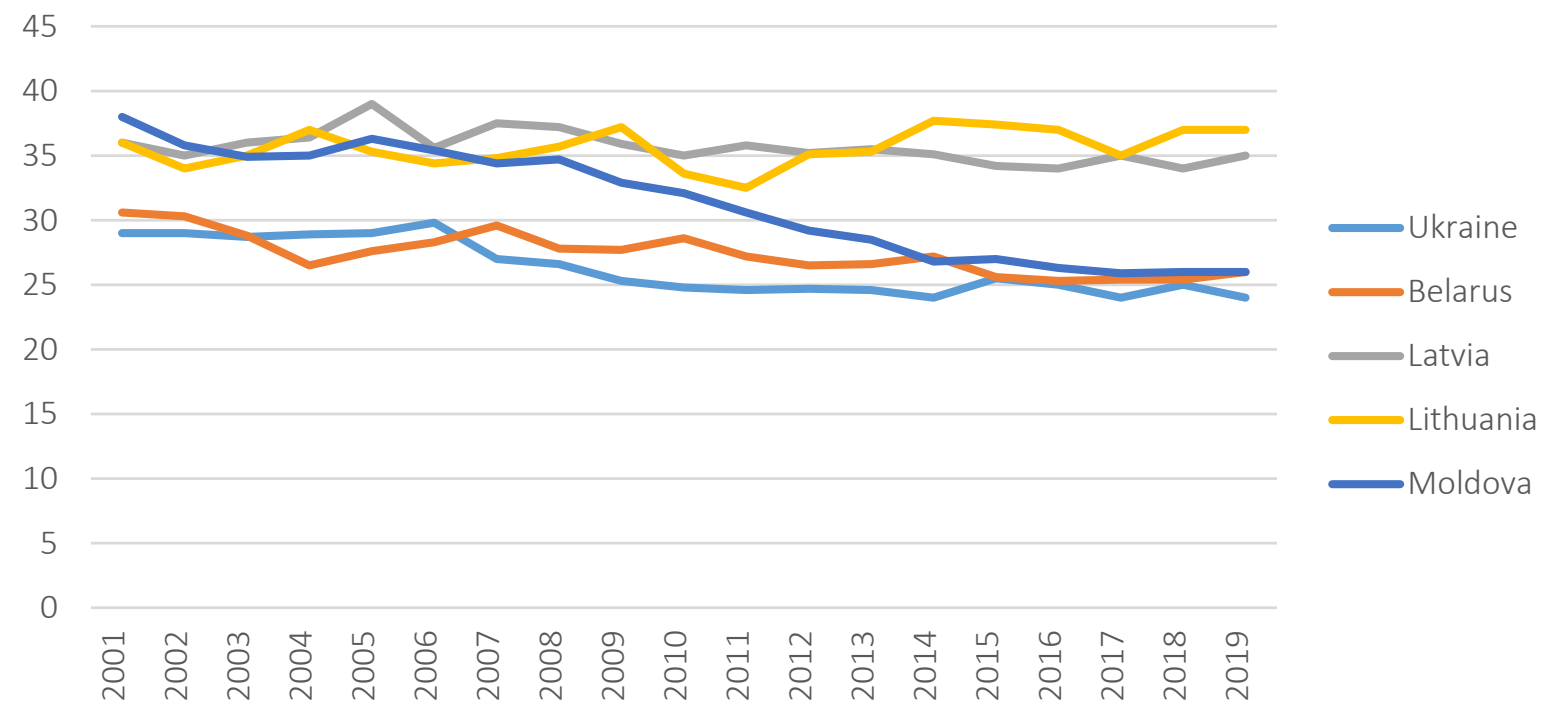

Figure 1. Gini index of the Eastern European countries for the period 2010-2019 


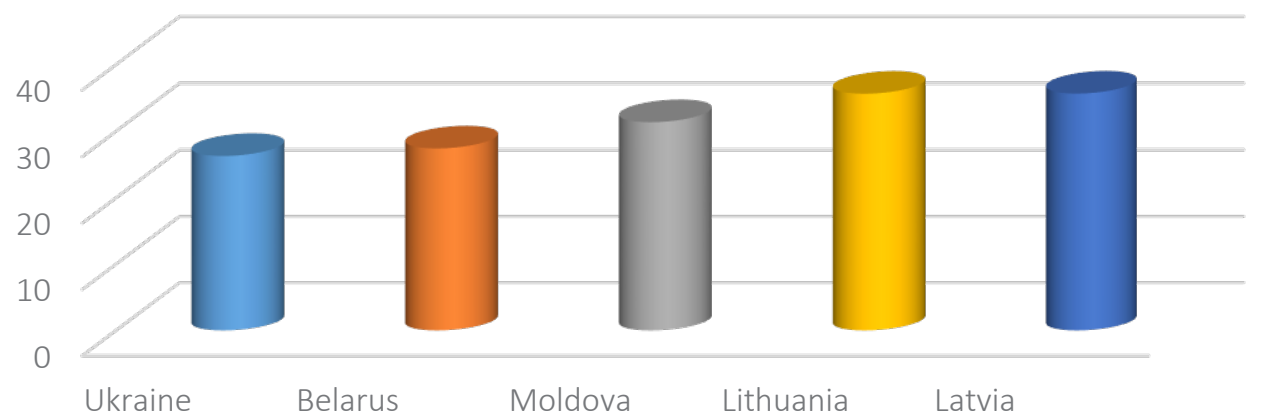

Figure 2. Average ranks of the Gini index of the Eastern European countries for the period 2010-2019

Table 3. System for studying the impact of modern business space "VUCA" on the analysis of financial stability of the country's banks

Source: Developed by the authors.

\begin{tabular}{|c|c|c|c|c|}
\hline VUCA & Drivers & Consequences & Requirements & Macroeconomic indicators \\
\hline \multirow{9}{*}{$\begin{array}{l}\text { Volatility } \\
\text { (variability) }\end{array}$} & Change of essence & Risks & Act & Adjusted net national income per capita (annual \% growth) \\
\hline & $\begin{array}{l}\text { Change of } \\
\text { dynamics }\end{array}$ & Flows & \multirow{8}{*}{$\begin{array}{l}\text { Reconfiguration of } \\
\text { research }\end{array}$} & Adjusted net national income per capita (current USD) \\
\hline & \multirow{7}{*}{$\begin{array}{l}\text { Speed of change } \\
\text { and movement }\end{array}$} & \multirow{7}{*}{ Instability } & & Exports of goods and services (\% of GDP) \\
\hline & & & & Final consumption expenditure (\% of GDP) \\
\hline & & & & GDP growth (annual \%) \\
\hline & & & & GNI growth (annual \%) \\
\hline & & & & Inflation, GDP deflator (annual \%) \\
\hline & & & & Lending interest rate (\%) \\
\hline & & & & Researchers in R\&D (per million people) \\
\hline \multirow{7}{*}{ Uncertainty } & Unpredictability & \multirow{7}{*}{$\begin{array}{l}\text { Inhibition due to } \\
\text { data overload }\end{array}$} & $\begin{array}{l}\text { Different } \\
\text { perspectives }\end{array}$ & Broad money (\% of GDP) \\
\hline & \multirow{6}{*}{ Potential benefits } & & \multirow{6}{*}{$\begin{array}{l}\text { Latitude of } \\
\text { understanding }\end{array}$} & Current account balance (\% of GDP) \\
\hline & & & & Expense (\% of GDP) \\
\hline & & & & External balance on goods and services (\% of GDP) \\
\hline & & & & GNI per capita growth (annual \%) \\
\hline & & & & Imports of goods and services (\% of GDP) \\
\hline & & & & Present value of external debt (\% of GNI) \\
\hline \multirow{8}{*}{ Complexity } & Task adjustment & Unproductivity & Clarity & Central government debt, total (\% of GDP) \\
\hline & Unknown results & \multirow{7}{*}{ Dualism } & Key review & GINI index (World Bank estimate) \\
\hline & $\begin{array}{l}\text { Changing the } \\
\text { dynamics }\end{array}$ & & Flexibility & Government expenditure on education, total (\% of GDP) \\
\hline & & & \multirow{5}{*}{ Creation } & Military expenditure (\% of GDP) \\
\hline & & & & Research and development expenditure (\% of GDP) \\
\hline & Multifaceted & & & Gross capital formation (\% of GDP) \\
\hline & consequences & & & $\begin{array}{l}\text { Market capitalization of listed domestic companies (\% of } \\
\text { GDP) }\end{array}$ \\
\hline & & & & Profit tax (\% of commercial profits) \\
\hline \multirow{7}{*}{ Ambiguity } & Perfect and actual & $\begin{array}{l}\text { Doubt and } \\
\text { mistrust }\end{array}$ & Mobility & $\begin{array}{l}\text { Current education expenditure, total (\% of total } \\
\text { expenditure in } \mathrm{PI})\end{array}$ \\
\hline & $\begin{array}{l}\text { Changing the } \\
\text { dynamics }\end{array}$ & Uncertainty & Problem solving & Current health expenditure (\% of GDP) \\
\hline & \multirow{5}{*}{$\begin{array}{l}\text { Wrong } \\
\text { interpretation }\end{array}$} & \multirow{5}{*}{$\begin{array}{l}\text { Errors in decision } \\
\text { making }\end{array}$} & \multirow{5}{*}{ Innovation } & Foreign direct investment, net inflows ( $\%$ of GDP) \\
\hline & & & & Foreign direct investment, net outflows (\% of GDP) \\
\hline & & & & Gross national expenditure (\% of GDP) \\
\hline & & & & Tax revenue (\% of GDP) \\
\hline & & & & Trade (\% of GDP) \\
\hline
\end{tabular}


country. Drivers, consequences, requirements and macroeconomic indicators of the country's activity in the context of the VUCA world are determined.

For a more detailed study of the research topic, the method of constructing the regression equation in multifactor regression analysis was used.

Linear multiple regression:

$$
\tilde{y}=a+b_{1} x_{1}+b_{2} x_{2}+\ldots+b_{k} x_{k} .
$$

The technique for constructing a regression equation in a four-way regression analysis $\bar{y}=a+b x_{1}+c x_{2}+d x_{3}+e x_{4}+f z$ leads to the following formulas for estimating parameters:

$$
\begin{aligned}
& b=\frac{r_{y x}-r_{y z} r_{x z}}{1-r_{x z}^{2}} \cdot \frac{\sigma_{y}}{\sigma_{x}}, \\
& b=\frac{r_{y z}-r_{y x} r_{x z}}{1-r_{x z}^{2}} \cdot \frac{\sigma_{y}}{\sigma_{z}}, \\
& a=\bar{y}-b \bar{x}-c \bar{z} .
\end{aligned}
$$

Next, a system of normal equations is constructed and parameters are determined, which should then be potentiated. Assessment of the closeness of the relationship and statistical significance in multiple regression is as follows:

1) multiple determination coefficient $R^{2}$ :

$$
R^{2}=1-\frac{\sigma_{b a l}^{2}}{\sigma_{y}^{2}}=\frac{\sum(\tilde{y}-\bar{y})^{2}}{\sum(y-\bar{y})^{2}},
$$

2) multiple correlation index $R$;

3) linear multiple correlation coefficient (for

$$
\begin{gathered}
\left.\tilde{y}=a+b_{1} x_{1}+b_{2} x_{2}+\ldots+b_{k} x_{k}\right), \\
R=\sqrt{\sum\left(\beta_{i} \cdot r_{y x_{i}}\right)},
\end{gathered}
$$

4) adjusted correlation index (coefficient):

$$
R_{\text {correct }}^{2}=1-\left(1-R^{2}\right) \cdot \frac{n-1}{n-k-1},
$$

where $k$ is the number of parameters for variables. In statistical software packages, in the multiple regression procedure, an adjusted multiple correlation (determination) coefficient (index) is usually given;
5) delta-coefficients $\Delta_{i}$

$$
\Delta_{i}=r_{y x_{i}} \cdot \frac{\beta_{i}}{R^{2}},
$$

where $r_{y x i}$ is the coefficient of pair correlation between $y$ and $x_{i} ; R^{2}$ is multiple coefficient of determination;

6) partial coefficients of elasticity:

$$
E_{i}=b_{i} \cdot \frac{\overline{x_{i}}}{\bar{y}},
$$

where $b_{i}$ is the coefficient of "pure" regression at the factor $x_{i} ; \bar{y}$ is the average value of the result factor; and $\bar{x}_{i}$ is the average value of the factor $x_{i}$.

The significance of the multiple regression equation in general is estimated using the Fisher F-test:

$$
F=\frac{R^{2}}{1-R^{2}} \cdot \frac{n-m-1}{m},
$$

where $n$ is the number of observations, $m$ is the number of parameters for the variable $x$.

If the calculated value of the criterion with $k_{1}=m$ and $k_{2}=n-m-1$ degrees of freedom is greater than the tabular value for a given level of significance, then the model is considered significant.

If the actual value of the criterion with $k_{1}=1$ and $k_{2}=n-m-1$ degrees of freedom is greater than the tabular value at a given significance level, then the additional inclusion of the factor $x_{p}$ in the model is justified statistically, and the regression coefficient for this factor is statistically significant.

So, the dependence of bank capital to assets ratio $(\%)(y)$ on GDP growth (annual\%)(X), GNI per capita growth (annual\%) $\left(X_{2}\right)$, research and development expenditure (\% of GDP) $\left(X_{3}\right)$ and foreign direct investment and net inflows (\% of GDP ) $\left(X_{4}\right)$ were studied according to the data of the five studied countries during 2001-2019.

It is necessary:

1. To calculate the parameters of a linear multiple regression equation with a full list of factors. 
2. To evaluate the significance of the equation as a whole, using the value of the multiple correlation coefficient and the general Fisher F-test.

3. To assess the statistical significance of the regression model parameters using the t-test.

4. To investigate collinearity between factors. If multicollinearity is present, exclude any factor from the regression equation.

5. To construct a new multiple regression equation, carry out all the necessary studies similar to those conducted above.

6. Based on the results, to find the average coefficients of elasticity of factor $y$ from independent factors.

\subsection{Assessment of the dependence of Bank capital to assets ratio on macroeconomic indicators}

1. Obtaining the calculation protocol. The operation is performed using the Data Analysis/ Regression tool. The analysis results are shown in Table 4.

2. The statistical significance in general is assessed. Having studied the results, it is noted that, in general, the obtained linear multiple regression equation

$$
\begin{aligned}
& \tilde{y}=5.71+0.15 x_{1}+0.06 x_{2}+ \\
& +0.12 x_{3}+0.04 x_{4},
\end{aligned}
$$

is statistically significant. Indeed, $F_{\text {calcul }}=64.63$. Let us compare this number with the critical value of the Fisher criterion obtained for the number of degrees of freedom $k_{1}=m$ and $k_{2}=n-m-1$, where $n$ is the number of observations, $m$ is the number of parameters for the variable $x$. In this case, $k_{1}=3$ and $k_{2}=14-3-1=10$. The critical value will be given by the function FINV. $F_{c r i t}=3.71$, which is significantly less than the calculated value.

It is best to estimate the proportion of variation of the effective trait $y$ explained by the constructed multiple regression equation by the value of the normalized correlation coefficient, in this case it is 0.9363 . That is, the constructed equation explains almost $94 \%$ of the entire variation of the attribute $y$.

3. Statistical significance was estimated by individual parameters. To assess the statistical significance of the regression model parameters using the $\mathrm{t}$-criterion, the critical value corresponding to the parameters should be found using the function TINV at a given significance level of 0.05 and the number of degrees of freedom $n-m-1$. The coefficient is considered significant if inequality is realized as $t_{\text {calcul }}>t_{\text {crit }}$.

Table 4. Summary of regression analysis results of the dependence of bank capital to assets ratio on macroeconomic indicators

\begin{tabular}{|c|c|c|c|c|}
\hline \multicolumn{5}{|c|}{ Analysis of variance } \\
\hline Variance & df & SS & MS & $\mathbf{F}$ \\
\hline Regression & 3 & 806.1446094 & 268.7148698 & 64.64204 \\
\hline Balance & 10 & 41.56967627 & 4.156967627 & - \\
\hline Total & 13 & 847.7142857 & - & - \\
\hline Coefficients & Value & Standard error & t-statistics & - \\
\hline Y-intersection & 5.711742473 & 6.18918556 & 0.922858495 & - \\
\hline$x 1$ & 0.148601283 & 0.340417689 & 0.436526326 & - \\
\hline$\times 2$ & 0.064880259 & 0.162051974 & 0.400366976 & - \\
\hline$\times 3$ & 0.124867552 & 0.432056322 & 0.134365123 & - \\
\hline$x 4$ & 0.037784221 & 0.033824423 & 1.11706919 & - \\
\hline
\end{tabular}

\begin{tabular}{l|c|c}
\hline & Regression statistics & \\
\hline Multiple R & 0.97517313 & - \\
R-square & 0.950962633 & - \\
\hline Normalized R-square & 0.936251423 & - \\
\hline Standard error & 2.038864298 & - \\
\hline Observations & 95 & - \\
\hline
\end{tabular}


Table 5 shows the results.

Table 5. Evaluation of the statistical significance of the regression model parameters with t-criterion

\begin{tabular}{l|c:c:c:c}
\hline t-criterion & $x_{1}$ & $x_{2}$ & $x_{3}$ & $x_{4}$ \\
\hline$t_{\text {calcul }}$ & 1.44 & 1.4 & 1.23 & 1.78 \\
\hdashline$t_{\text {crit }}$ & 1.2281 & & & \\
\hline
\end{tabular}

Thus, all factors have statistically significant regression coefficients, and the constructed equation is suitable for prediction.

4. Let us investigate the collinearity between the factors. To estimate the multicollinearity of the factors, the determinant of matrix of paired correlation coefficients of factors is calculated.

$$
\begin{aligned}
& \operatorname{Det}|R|=\left|\begin{array}{lll}
a_{x 1 x 1} & a_{x 2 x 1} & a_{x 3 x 1} \\
a_{x 1 x 2} & a_{x 2 x 2} & a_{x 3 x 2} \\
a_{x 1 x 3} & a_{x 2 x 3} & a_{x 3 x 3}
\end{array}\right|= \\
& =\left|\begin{array}{ccc}
1 & 0.36 & 0.99 \\
0.36 & 1 & 0.42 \\
0.99 & 0.42 & 1
\end{array}\right| \approx 1.01 .
\end{aligned}
$$

Since the determinant of the interfactor correlation matrix is not close to zero, there is no multicollinearity of factors.

The significance of the multicollinearity of factors can be assessed by testing the variable independence hypothesis, i.e.

\section{HO: $\quad \operatorname{Det}|R|=1$.}

It is proved that the quantity $\theta=[n-1-1 / 6(2 m$ +5) $\lg$ Det $|R|]$ has an approximate distribution $\chi^{2}$ with the number of degrees of freedom $1 / 2 m(m-$ 1). If the actual value $\chi^{2}$ exceeds the tabular (critical) value, the hypothesis $H 0: \operatorname{Det}|R|=1$ is rejected, and multicollinearity is considered proven.

$$
\begin{aligned}
& \theta=14-1-1 / 6(2 \cdot 3+5) \lg 0.01= \\
& 13-11 / 6(-2)=13+11 / 3 \approx 16.67 .
\end{aligned}
$$

The critical value $\chi^{2}$ can be found through the statistical function $\operatorname{CHIINV}(\alpha ; n-1)$, where $\alpha$ is the level of significance (condition 0.05), and $n$ is the number of degrees of freedom. In this case, degrees of freedom $1 / 2 \cdot 3(3-1)=3 \cdot \chi_{\text {critical }}^{2}=7.8$, $\chi_{\text {critical }}^{2}<\theta$ are received. The multicollinearity of factors cannot be neglected.

5. Find the coefficients of elasticity:

$$
E_{i}=b_{i} \cdot \frac{\overline{x_{i}}}{\bar{y}},
$$

where $b_{i}$ is the coefficient of "pure" regression at the factor $x ; \bar{y}$ is the average value of the result factor; and $\bar{x}_{i}$ is the average value of the factor $x_{i}$.

There is elasticity $X_{1}=0.11, X_{2}=0.03, X_{3}=0.72, X_{4}$ $=0.54, \bar{y}=5.71+0.11 X_{1}+0.03 X_{2}+0.72 X_{3}+0.54 X_{4}$. Thus, when the factor $X_{1}$ (GDP growth) changes by $1 \%$, bank capital to assets ratio increases by $0.11 \%$; when $X_{2}$ (GNI per capita growth) increases by $1 \%$, bank capital to assets ratio increases slightly, by $0.03 \%$; with the change of the factor $X_{3}$ (research and development expenditure) by $1 \%$, bank capital to assets ratio increases by $0.72 \%$; when the factor $X_{4}$ (foreign direct investment, net inflows) changes by $1 \%$, bank capital to assets ratio increases by $0.54 \%$. Thus, in the conditions of the VUCA world, the financial stability of banks is most influenced by the following indicators: research and development expenditure and foreign direct investment, net inflows.

The assessment, in contrast to the existing ones, makes it possible to take into account the impact of the macroeconomic environment on the financial stability of banks. It is important to introduce into the practice of banks preventive scientific and methodological approaches to the rapid diagnosis of their financial stability.

\section{DISCUSSION}

Banking institutions around the world are constantly influenced by international globalization processes. They constantly affect both qualitative and quantitative characteristics of financial stability of banks, which, in turn, requires constant monitoring and analysis. This is confirmed by Codreanu (2016), who writes that instability captures sudden, extreme and multi-layered fluctuations in economics, sociopolitics, geopolitics, as 
well as creates difficulties in identifying and describing these changes compared to the previous stable world confidence. But the question arises whether the prospect of a VUCA-world solution is only a re-emphasis on ideas that already underlie traditional management approaches.

Singhwal (2018) states that financial problems are one of the most painful that entrepreneurs and businesses have to face. But it can be argued that the financial challenges of the global economy also affect the performance of financial institutions. Sinha (2020) notes that to survive and thrive in a leadership role and successfully emerge as a winner in an era of chaos and complexity, managers will have to constantly adapt, which is becoming increasingly inevitable in the VUCA world. However, it will be necessary to adapt not only to managers, but also to key personnel, and not only in order to gain leadership positions, but also to simply to be able to work in this market.

Shukla (2014) argues that the experience gained by the bank of different countries after the recent global financial crisis has allowed the bank to reconsider and update its approach to the factors that determine its activities and future profitability. However, many banks around the world have been forced to close due to the global financial crisis. Li (2020) notes that leverage ratio regulation will lead to unfavorable selection, thereby increasing the credit risk of commercial banks. This is due to the fact that large banks are more likely to take high-risk actions to make a profit, which leads to the accumulation of credit risks in commercial banks. But, financial stability directly depends on the system used to reduce the risks of commercial banks.

Dzhafarova et al. (2018) state that for Ukraine, European integration, on the one hand, is a way to modernize the economy, attract foreign investment and technologies, increase the competitiveness of native producers, and enter world markets, including the financial services market. On the other hand, entering world markets, formation of an open economy also means that banks must be internally stable, able to withstand risks, the processes of globalization and European integration. This is also confirmed by Kreidych et al. (2018), since in the context of globalization conflicts, with simultaneous localization of economies, confrontation of political systems and meta-goals, the only way to increase financial stability of banks is to apply a systemic approach that covers all aspects of development. All of the above proves the need for an urgent further search for tools to analyze the financial stability of banks.

\section{CONCLUSION}

The study showed that the analysis of financial stability of banking institutions should be based on the characteristics of the VUCA world, the unpredictability of the future due to the rapid development of events, the use of tools for studying the environment and the formation of an adequate response from the banking institution as an adaptive response to changes and VUCA-answer, which is focused on the competence of specialists. The main emphasis should be on scanning and flexible situational decision-making, taking into account macroenvironmental factors. A theoretical model has been developed for studying the impact of the modern business space "VUCA" on the analysis of the financial stability of banks in the country, including drivers, consequences, requirements and macroeconomic indicators.

During the study, a tool for monitoring the impact of the VUCA world conditions on the financial stability of banks was proposed, namely, based on a theoretical model for studying the influence of the modern business space "VUCA", an econometric model was developed for analyzing the impact of the VUCA world on the financial stability. Thus, when GDP growth changes by $1 \%$, bank capital to assets ratio increases by $0.11 \%$; when GNI per capita growth increases by $1 \%$, bank capital to assets ratio slightly increases by $0.03 \%$; with a change of the research and development expenditure by $1 \%$, bank capital to assets ratio increases by $0.72 \%$; when the foreign direct investment and net inflows change by $1 \%$, bank capital to assets ratio increases by $0.54 \%$. 
The study showed that among the studied indicators in the VUCA world, the financial stability of banks is most influenced by indicators such as research and development expenditure and foreign direct investment. Conducting research, in contrast to the existing ones, makes it possible to consider the impact of the macroeconomic environment on the financial stability of banks.

\section{AUTHOR CONTRIBUTIONS}

Conceptualization: Svitlana Khalatur.

Data curation: Svitlana Khalatur, Olena Pavlenko.

Formal analysis: Svitlana Khalatur, Liudmyla Velychko.

Funding acquisition: Svitlana Khalatur, Liudmyla Velychko.

Investigation: Svitlana Khalatur, Liudmyla Velychko, Olena Pavlenko, Mariia Huba.

Methodology: Svitlana Khalatur, Liudmyla Velychko, Oleksandr Karamushka.

Project administration: Svitlana Khalatur, Olena Pavlenko.

Resources: Liudmyla Velychko, Olena Pavlenko.

Software: Liudmyla Velychko, Olena Pavlenko, Oleksandr Karamushka, Mariia Huba.

Supervision: Svitlana Khalatur, Liudmyla Velychko, Oleksandr Karamushka, Mariia Huba.

Validation: Oleksandr Karamushka, Mariia Huba.

Visualization: Olena Pavlenko, Oleksandr Karamushka, Mariia Huba.

Writing - original draft: Svitlana Khalatur.

Writing - reviewing \& editing: Svitlana Khalatur, Liudmyla Velychko, Olena Pavlenko, Oleksandr

Karamushka, Mariia Huba.

\section{REFERENCES}

1. Banae Costa, C. A., \& Chagas, M. P. (2004). A career choice problem: an example of how to use MACBETH to build a quantitative value model based on qualitative value judgments. European Journal of Operational Research, 153(2), 323-331. Retrieved from https://ideas.repec.org/a/eee/ejores/v153y2004i2p323-331.html

2. Batischeva, G. A., Denisov, M. Yu., Rybchinskaya, I. V., \& Stryukov, M. B. (2018). Regional Development and Banking Activities. European Research Studies Journal, 21(1), 455-465. https://doi.org/10.35808/ ersj/1195

3. Bortnyk, N., Tsurcan-Saifulina, J., \& Kotukha, O. (2018). Essence and content of category "financial investigations" and concept development amid European integration. Baltic Journal of Economic Studies, 4(5), 36-39. https://doi. org/10.30525/2256-0742/2018-45-36-39

4. Cenkhan, S., de Haan, J., \& Neretina, E. (2020). Banking stress test effects on returns and risks. Journal of Banking \& Finance, 117(C),
105843. https://doi.org/10.1016/j. jbankfin.2020.105843

5. Codreanu, A. (2016). A VUCA action framework for a VUCA environment. Leadership challenges and solutions. Journal of Defense Resources Management, 7(2), 3138. Retrieved from http://journal dresmara.ro/issues/volume7_issue2/03_codreanu_vol7_issue2. pdf

6. Cont, R., Kotlicki, A., \& Valderrama, L. (2020). Liquidity at risk: Joint stress testing of solvency and liquidity. Journal of Banking \& Finance, 118, 105871. https://doi.org/10.1016/j.jbankfin.2020.105871

7. Dardac, N., \& Boitan, I. (2009). A Simple Early Warning System for Evaluating the Credit Portfolio's Quality. Theoretical and Applied Economics, 5(05), 69-78. Retrieved from https://ideas.repec.org/a/ agr/journl/v05(534)y2009i05(534) p69-78.html

8. Donatosi, G. S., \& Giokas, D. I. (2008). Relative Efficiency in the branch network of a Greek bank:
A quantitative analysis. European Research Studies, 11(3), 53-72. Retrieved from https://www.ersj.eu/ repec/ers/papers/08_3_p4.pdf

9. Dzhafarova, O., Riabchenko, O. \& Artemenko, I. (2018). Structural and legal analysis of banking safety in Ukraine. Baltic Journal of Economic Studies, 4(5), 67-74 https://doi.org/10.30525/22560742/2018-4-5-67-74

10. Halunko, V., Halunko, V., \& Savyuk, M. (2018). Foreign experience for financing small and medium business. Baltic Journal of Economic Studies, 4(5), 40-45. https://doi.org/10.30525/22560742/2018-4-5-40-45

11. Keesoony, S. (2016). International anti-money laundering laws: the problems with enforcement. Journal of Money Laundering Control, 19(2), 130-147. https://doi. org/10.1108/JMLC-06-2015-0025

12. Khalatur, S., Pavlova, G., \& Zhylenko, K. (2018). The role of some indicators of financial security in Ukraine in the context of transnationalization and national 
interests. Investment Management and Financial Innovations, 15(3), 237-248. https://doi.org/10.21511/ imfi.15(3).2018.20

13. Konig, E. (2017). Implementing an efficient resolution framework in the Banking Union: lessons from the crisis and challenges ahead. Financial Stability Review, 21, 71-76. Retrieved from https:// publications.banque-france.fr/ sites/default/files/medias/documents/fsr21_web.pdf

14. Kreidych, I., Roshchyna, N., \& Kazak, O. (2018). The application of monetary incentive policy in current economic conditions. Baltic Journal of Economic Studies, 4(5), 129-139. https://doi. org/10.30525/2256-0742/2018-45-129-139

15. Li, L. (2020). Regulation of Leverage Ratio, Credit Expansion and Credit Risk of Commercial Banks. Open Journal of Social Sciences, 8, 376-396. https://doi.org/10.4236/ jss.2020.84027

16. Lietava, M., \& Fáziková, M. (2017). Selection of EU financed projects and the territorial cohesion. Acta Oeconomica Universitatis Selye, 6(1), 71-82.

17. Nangia, M., \& Mohsin F. (2020). Identifying VUCA Factors in A Pandemic Era - A Framework Focused on Indian It Industry. Journal of Critical Reviews, 7(7), 931936. http://dx.doi.org/10.31838/ jcr.07.07.169

18. Nidar, S. R., Anwar, M., Komara, R., \& Layyinaturrobaniyah, L. (2020). Determinant of regional development bank efficiency for their sustainability issues. Entrepreneurship and Sustainability Issues, 8(1), 1133-1145. http://doi. org/10.9770/jesi.2020.8.1(76)

19. Rakhmetova, A., Kalkabayeva, G., Kurmanalina, A., Gusmanova, Z., Serikova, G., \& Aimurzina, B. (2020). Financial-credit and innovative economic sectors: evaluation of macroeconomic effects of regulation and interaction sectors. Entrepreneurship and Sustainability Issues, 8(1), 1224-1237. http:// doi.org/10.9770/jesi.2020.8.1(82)
20. Shchenin, R. (2010). Banking systems of the countries of the world: a training manual. M.: KNORUS, $400 \mathrm{p}$.

21. Shukla, S. (2014). Analysis of Banking System Performance of Select Global Economies with That of India - During and After the Global Financial. Procedia Economics and Finance, 11, 383395.

22. Shuyan, L., \& Fabuš, M. (2019). Study on the spatial distribution of China's Outward Foreign Direct Investment in EU and its influencing factors. Entrepreneurship and Sustainability Issues, 6(3), 1280-1296. http://doi. org/10.9770/jesi.2019.6.3(16)

23. Singhwal, N. (2018). Financial Challenges in VUCA World. In 2nd International Conference on "Innovative Business Practices and Sustainability in VUCA World" (pp. 137-142). Retrieved from http://www.iosrjournals.org/ iosr-jbm/papers/Conf.180112018/Volume-2/Finance/18.\%20 137-142.pdf

24. Sinha, D. (2020). Managing in a VUCA World: Possibilities and Pitfalls. Journal of Technology Management for Growing Economies, 11(1), 17-21. http://doi. org/10.15415/jtmge.2020.111003

25. State Committee of Statistics of Ukraine. (n.d.). Official site. Retrieved from http://www.ukrstat. gov.ua

26. Velychko, O., \& Velychko, L. (2017). Logistical modelling of managerial decisions in social and marketing business systems. Journal of International Studies, 10(3), 206-219. http:// dx.doi.org/10.14254/20718330.2017/10-3/15

27. Wang, J., Lee, Y.-N., \& Walsh, J. (2018). Funding model and creativity in science: Competitive versus block funding and status contingency effects. Research Policy, 47(6), 1070-1083. https://doi. org/10.1016/j.respol.2018.03.014

28. World Bank. (n.d.). Retrieved from http://www.worldbank.org
29. Zavadska, D. (2018). Determining the role of banks in the financing of innovative development processes of the economy. Baltic Journal of Economic Studies, 4(3), 68-73. https://doi. org/10.30525/2256-0742/2018-4$3-68-73$ 